\title{
PHENOTYPIC DIFFERENCE BETWEEN SMOKER AND NON- SMOKER CHRONIC OBSTRUCTIVE PULMONARY DISEASE
}

\author{
Deependra Kumar Rai1, Abhishek Kumar², Ashish Anshuman³, Jwala Kumar ${ }^{4}$, Abhishek kumar', Somesh thakur ${ }^{6}$ \\ ${ }^{1}$ Assistant Professor \& HOD, Department of Pulmonary Medicine, AIIMS, Patna. \\ ${ }^{2}$ Senior Resident, Department of Pulmonary Medicine, AIIMS, Patna. \\ 3 Junior resident, Department of Pulmonary Medicine, AIIMS, Patna. \\ 4 Junior resident Department of Pulmonary Medicine, AIIMS, Patna. \\ 5 Junior resident Department of Pulmonary Medicine, AIIMS, Patna. \\ ${ }^{6}$ Assistant Professor, Department of Pulmonary Medicine, AIIMS, Patna.
}

ABSTRACT
BACKGROUND
Smoking is one of the major risk factor associated with COPD. Other risk factors could be exposure to biomass fuel (in females), air
pollution, occupational factors, etc. There are few studies that really characterise smoker \& non-smoker COPD phenotype so that
treatment can be individualised.
Aim- The study was designed to assess phenotypic differences between smoker \& non-smoker COPD.

\section{MATERIALS \& METHODS}

All consecutive patients with confirmed diagnosis of COPD in Department of Pulmonary Medicine in the month of July 2016 were included in the study. We compared smoker and non-smoker COPD with set parameters such as COPD grade, frequency of exacerbation, associated comorbidities like diabetes, hypertension, BMI, clinical symptom, lung function parameters. Non-smokers were defined as having <1-pack year of tobacco exposure; otherwise, the patients were classified as smokers.

\section{RESULTS}

A total of 78 stable COPD patients who were not in exacerbation included in study. The average age was 59.4 \& 61.4 years in nonsmoker \& smoker COPD cases respectively. FEV1 and FVC were significantly lower in non-smokers (0.74 L, 1.44 L) with COPD than in smokers $(0.83 \mathrm{~L}, 1.74 \mathrm{~L})$ with COPD. Cough $(76.3 \%$ vs. $65 \%)$ \& sputum production $(60.5 \%$ vs. $36.5 \%)$ was more prevalent in smoker COPD. History of more than one exacerbation was detected more in smoker COPD (36.8\% vs. $30 \%$ ). Severe $\&$ very severe COPD was more prevalent in non-smokers when compared to smokers, but moderate COPD was more frequent in smokers.

\section{CONCLUSION}

COPD patients who are smokers have more symptoms of chronic bronchitis like cough with expectoration and have more frequent exacerbations when compared to non-smokers. Hypertension and cor pulmonale was detected more in COPD patients who are non-smokers.

\section{KEYWORDS}

COPD, Smoker, Non-smoker, Pulmonary Function, Exacerbation.

HOW TO CITE THIS ARTICLE: Rai DK, Kumar A, Anshuman A, et al. Phenotypic difference between smoker and non-smoker chronic obstructive pulmonary disease. J. Evolution Med. Dent. Sci. 2017;6(30):2442-2445, DOI: 10.14260/Jemds/2017/527

\begin{abstract}
BACKGROUND
Chronic obstructive pulmonary disease (COPD) is one of the leading causes of morbidity and mortality worldwide, and represents a huge and growing economic and social burden. ${ }^{1}$ Chronic obstructive pulmonary disease (COPD) is characterised by progressive airflow obstruction and destruction of lung parenchyma, and is caused by chronic exposure of genetically susceptible individuals to environmental factors. The association between tobacco smoking with risk of COPD has been known since 1950s.2-3 Smoking was established as a causative risk factor by the
\end{abstract}

Financial or Other, Competing Interest: None.

Submission 08-02-2017, Peer Review 30-03-2017,

Acceptance 05-04-2017, Published 13-04-2017.

Corresponding Author:

Dr. Deependra Kumar Rai,

Assistant Professor,

Department of Pulmonary Medicine,

AIIMS Patna.

E-mail: deependra78@gmail.com

DOI: $10.14260 /$ jemds $/ 2017 / 527$

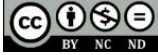

findings of Fletcher and Peto's 4 8-year prospective study of 792 men, and the larger and longer Framingham cohort offspring study confirmed these results. ${ }^{5}$ As little as $50 \%$ of cases worldwide are related to smoking ${ }^{3}$ and an estimated $10 \%-12 \%$ of individuals with COPD have never smoked. ${ }^{6}$ Analysis of data from the international, population-based Burden of Obstructive Lung Disease (BOLD) study showed that $23.3 \%$ of subjects with Global Initiative for Chronic Obstructive Lung Disease (GOLD) grade 2-4 COPD were never smokers. ${ }^{7}$

Very few studies investigated the non-smoking phenotype of COPD or compared with the smoking phenotype. RamírezVenegas and colleagues ${ }^{8}$ reported that Mexican women who had COPD and had been exposed to smoke from biomass fuel had similar clinical characteristics, quality of life, and mortality of those with COPD due to tobacco smoking. However, Shavelle and co-workers ${ }^{9}$ showed that in US patients with COPD the reduction in life expectancy was less for those who had never smoked than for those with COPD due to smoking. 
The purpose of the study is to compare smoker \& nonsmoker COPD in clinical presentation, lung function and frequency of exacerbation.

\section{Objectives}

1. To measure differences in clinical presentation between smoker \& non-smoker COPD.

2. To assess difference in pulmonary function between smoker \& non-smoker COPD.

3. To assess differences in comorbidities between smoker \& non-smoker COPD.

\section{MATERIALS AND METHODS}

The study was carried by Department of Pulmonary Medicine, All India Institute of Medical Sciences, Patna.

\section{Study Design}

Hospital based cross-sectional study.

\section{Inclusion Criteria}

All patients who were diagnosed as COPD with age $>40$ years in Department of Pulmonary Medicine, All India Institute of Medical sciences, Patna in July 2016 were included in study.

\section{Exclusion Criteria}

1. Subjects with other lung diseases such as pulmonary tuberculosis, bronchiectasis, pneumonia, interstitial lung disease, or pleural effusion, were also excluded, as were patients who had airflow limitation due to abnormalities in the large airways.

2. Subjects who were diagnosed COPD outside of AIIMS.

3. Patients with exacerbation in last one month are excluded.

\section{Data Collection}

The data were collected with pre-design Proforma (Given below).

The following information was collected: Patient's age, sex, smoking status (Never smoker, ever smoker, current smoker), quantity of tobacco smoking exposure (Pack-years), respiratory symptoms (Chronic cough, chronic sputum, a history of/or concurrent wheezing), modified Medical Research Council Dyspnoea Score, exacerbation in last one year and comorbidity (Hypertension, coronary heart disease, Osteoporosis, diabetes, etc.).

\section{Definitions}

The lung function tests had been performed according to ATS guidelines using calibrated PFT equipment (Jaeger Co, Würzburg, Germany). The diagnosis of COPD was according to the GOLD definition. Briefly, COPD was considered to be present if post-bronchodilator forced expiratory volume in the first second of expiration $\left(\mathrm{FEV}_{1}\right) /$ forced vital capacity (FVC) ratio was less than 0.70. Significant bronchodilator reversibility was defined as an increase in $\mathrm{FEV}_{1}$ or FVC of at least $12 \%$ and $200 \mathrm{~mL}$, respectively, from baseline values.

The grade of COPD based on pulmonary function \& dyspnoea was classified as shown below in Table 6. The severity of airflow obstruction was assessed by postbronchodilator FEV1 ( $>80 \%$ mild, $50-80 \%$ moderate, $30-50 \%$ severe, $<30 \%$ very severe).
Non-smokers were defined as having $<1$ pack-years of tobacco exposure; otherwise, the patients were classified as smokers.

\section{Outcome (Variable)}

We compared smokers and non-smokers with set parameters.

1. COPD grade.

2. Frequency of exacerbation.

3. Associated comorbidities (Diabetes, Hypertension).

4. BMI.

5. Dyspnoea (mMRC scale $>1$ ).

6. Lung function parameters.

\section{Statistical Analysis}

The continuous data expressed as the mean and bivariate analysis were performed using unpaired t-tests and Pearson correlation. For discrete data Chi-squared value has been used. All Data were entered and analysed using SPSS software (SPSS Inc. Released 2009. PASW Statistics for Windows, Version 18.0. Chicago: SPSS Inc.).

\section{RESULTS}

A total of 78 stable COPD patients who were not in exacerbation were included in study. The average age was $59.4 \& 61.4$ years in non-smoker \& smoker COPD cases respectively. $84.2 \%(32 / 38)$ patients in smoker group and $42.5 \%(17 / 40)$ patients in non-smoker group were male. Baseline characteristics of COPD patients are given below in Table 1.

FEV1 and FVC were significantly lower in non-smokers $(0.74 \mathrm{~L}, 1.44 \mathrm{~L})$ with COPD than in smokers $(0.83 \mathrm{~L}, 1.74 \mathrm{~L})$ with COPD. But these differences could be due to gender difference between non-smokers and smokers \& to avoid this percentage predicted was used to analyse differences in lung function parameters. FEV1 percentage (38.2 vs. 36.9) and FVC percentage (63.1 vs. 58.2 ) predicted was higher in nonsmokers with COPD than in smokers with COPD. The FEV1/FVC percentage predicted was higher in non-smokers when compared to smokers (55.7 vs. 55.1) as shown in Table 2 .

Cough $(76.3 \%$ vs. $65 \%) \&$ sputum production $(60.5 \%$ vs. $36.5 \%$ ) was more prevalent in smoker COPD when compared to non-smoker COPD. Dyspnoea with severity of more than 1 mMRC was found in similar number of patients. Cor pulmonale was detected in $10 \%$ patients of non-smoker COPD. History of more than one exacerbation was detected more in smoker COPD cases (36.8\% vs. $30 \%$ ) (Table 3, Figure 2).

Overall, among all the patients with COPD, 20.5\%, 41\%, and $38.4 \%$ respectively, had moderate (grade 2), severe (grade 3), and very severe disease (grade 4). There was no patient with grade 1 (GOLD) COPD. Severe \& very severe COPD was more prevalent in non-smokers compared to smokers but moderate COPD was more frequent in smokers. Most of the patients of COPD (64.1\%) belong to class C according to GOLD classification. Class A \& C COPD more frequent in non-smokers whereas Class B \& Class D were more frequent in smoker COPD. If we look on comorbidities, hypertension was detected more in non-smoker COPD compared to smoker COPD (30\% vs. 13.5\%) (Table 4). 


\begin{tabular}{|c|c|c|c|}
\hline Characteristics & $\begin{array}{c}\text { Non- } \\
\text { smoker CoPD } \\
(\mathbf{n = 4 0 )}\end{array}$ & $\begin{array}{c}\text { Smoker } \\
\text { CoPD } \\
(\mathbf{n = 3 8})\end{array}$ & P value \\
\hline Age (Years) & 59.4 & 61.4 & 0.473 \\
\hline Sex (Male \%) & $\begin{array}{c}17 / 40 \\
(42.5 \%)\end{array}$ & $\begin{array}{c}32 / 40 \\
(84.2 \%)\end{array}$ & $\begin{array}{c}\text { Chi-square } \\
=14.51 ; \\
\mathrm{p}=0.0001\end{array}$ \\
\hline BMI & 22.2 & 20.1 & 0.854 \\
\hline $\begin{array}{c}\text { Smoking duration } \\
\text { (Yrs.) }\end{array}$ & 6.82 & N/A \\
\hline \multicolumn{4}{|r|}{ Table 1. Baseline Characteristic of Study Patients } \\
\hline
\end{tabular}

\begin{tabular}{|c|c|c|c|}
\hline $\begin{array}{c}\text { Spirometric } \\
\text { Variable }\end{array}$ & $\begin{array}{c}\text { Non-smoker } \\
\text { COPD } \\
\text { (n= 40) }\end{array}$ & $\begin{array}{c}\text { Smoker } \\
\text { with COPD } \\
\text { (n =38) }\end{array}$ & P value \\
\hline FEV1 (L) & 0.74 & 0.83 & 0.123 \\
\hline $\begin{array}{c}\text { FEV1\% } \\
\text { predicted }\end{array}$ & 38.2 & 36.9 & 0.056 \\
\hline FVC (L) & 1.44 & 1.74 & 0.008 \\
\hline $\begin{array}{c}\text { FVC \% } \\
\text { predicted }\end{array}$ & 63.1 & 58.2 & 0.415 \\
\hline FEV1/FVC \% & 55.7 & 51.1 & 0.245 \\
\hline $\begin{array}{c}\text { Table 2. Comparisons of Spirometric Variables between } \\
\text { Non-smokers and Smokers with COPD }\end{array}$ \\
\hline
\end{tabular}

\begin{tabular}{|c|c|c|c|c|}
\hline & $\begin{array}{c}\text { Non- } \\
\text { smoker } \\
\text { COPD } \\
(n=40)\end{array}$ & $\begin{array}{c}\text { Smoker } \\
\text { COPD } \\
(n=38)\end{array}$ & $\begin{array}{c}\text { Total } \\
(n=78)\end{array}$ & $\begin{array}{c}\text { Chi-square; } \\
\text { P-value }\end{array}$ \\
\hline $\begin{array}{c}\text { Chronic } \\
\text { Cough }\end{array}$ & $\begin{array}{c}26 \\
(65 \%)\end{array}$ & $\begin{array}{c}29 \\
(76.3 \%) \\
\end{array}$ & $\begin{array}{c}55 \\
(70.51 \%) \\
\end{array}$ & $\begin{array}{l}0.72 ; \\
0.396\end{array}$ \\
\hline $\begin{array}{c}\text { Sputum } \\
\text { Production }\end{array}$ & $\begin{array}{c}15 \\
(37.5 \%)\end{array}$ & $\begin{array}{c}23 \\
(60.5 \%)\end{array}$ & $\begin{array}{c}38 \\
(48.71 \%)\end{array}$ & $\begin{array}{l}3.265 ; \\
0.070\end{array}$ \\
\hline $\begin{array}{c}\text { SOB } \\
(\mathrm{mMRC})>1\end{array}$ & $\begin{array}{c}38 \\
(95 \%) \\
\end{array}$ & $\begin{array}{c}37 \\
(97.3 \%) \\
\end{array}$ & $\begin{array}{c}75 \\
(96.15 \%) \\
\end{array}$ & $\begin{array}{c}0.0021 ; \\
0.963 \\
\end{array}$ \\
\hline $\begin{array}{c}\text { h/o Cor } \\
\text { pulmonale }\end{array}$ & $4(10)$ & $\begin{array}{c}0 \\
(0 \%)\end{array}$ & $4(5 \%)$ & $\begin{array}{l}2.213 \\
0.136\end{array}$ \\
\hline $\begin{array}{c}>\text { One } \\
\text { exacerbation } \\
\text { in previous } \\
\text { year }\end{array}$ & $\begin{array}{c}12 \\
(30 \%)\end{array}$ & $\begin{array}{c}14 \\
(36.8 \%)\end{array}$ & $\begin{array}{c}26 \\
(33.3 \%)\end{array}$ & $\begin{array}{l}0.41 \\
0.632\end{array}$ \\
\hline
\end{tabular}

\begin{tabular}{|c|c|c|c|}
\hline Severity & $\begin{array}{c}\text { Non- } \\
\text { smoker } \\
\text { COPD } \\
(n=40)\end{array}$ & $\begin{array}{c}\text { Smoker } \\
\text { COPD } \\
(n=38)\end{array}$ & $\begin{array}{c}\text { Total } \\
(n=78)\end{array}$ \\
\hline $\begin{array}{c}\text { Grade } 1 \\
\text { (Mild) COPD }\end{array}$ & 0 & 0 & 0 \\
\hline $\begin{array}{c}\text { Grade } 2 \\
\text { (moderate) } \\
\text { COPD }\end{array}$ & $5(12.5 \%)$ & $11(28.9 \%)$ & $16(20.5 \%)$ \\
\hline $\begin{array}{c}\text { Grade } 3 \\
\text { (Severe) } \\
\text { COPD } \\
\end{array}$ & 18 (45\%) & $14(36.8 \%)$ & $32(41 \%)$ \\
\hline $\begin{array}{l}\text { Grade } 4 \text { COPD } \\
\text { (Very severe) }\end{array}$ & 17 (42.5\%) & 13 (34.2\%) & $30(38.4)$ \\
\hline \multicolumn{4}{|l|}{ COPD Class } \\
\hline $\mathrm{A}$ & $2(5 \%)$ & $1(2.6 \%)$ & $3(3.8 \%)$ \\
\hline $\mathrm{B}$ & $4(10 \%)$ & $8(21.0 \%)$ & $12(15.3 \%)$ \\
\hline $\mathrm{C}$ & $29(72.5 \%)$ & $21(55.26 \%)$ & $50(64.1 \%)$ \\
\hline $\mathrm{D}$ & $5(12.5 \%)$ & $8(21.0 \%)$ & $13(16.6 \%$ \\
\hline $\begin{array}{r}\text { Table 4. Co } \\
\text { COPD Clas }\end{array}$ & $\begin{array}{l}\text { mparison be } \\
\text { s between } S n\end{array}$ & $\begin{array}{l}\text { ween Severity } \\
\text { oker \& Non-st }\end{array}$ & $\begin{array}{l}\text { COPD and } \\
\text { ker COPD }\end{array}$ \\
\hline
\end{tabular}

\begin{tabular}{|c|c|c|c|c|}
\hline Comorbidities & $\begin{array}{c}\text { Non- } \\
\text { smoker } \\
\text { COPD } \\
(\mathbf{n = 4 0 )}\end{array}$ & $\begin{array}{c}\text { Smoker } \\
\text { COPD } \\
(\mathbf{n = 3 8})\end{array}$ & $\begin{array}{c}\text { Total } \\
(\mathbf{n}=\mathbf{7 8})\end{array}$ & $\begin{array}{c}\text { Chi- } \\
\text { square; } \\
\text { P-value }\end{array}$ \\
\hline Hypertension & $\begin{array}{c}12 \\
(30 \%)\end{array}$ & $\begin{array}{c}5 \\
(13.15 \%)\end{array}$ & $\begin{array}{c}17 \\
(21.7 \%)\end{array}$ & $\begin{array}{c}3.083 ; \\
0.096\end{array}$ \\
\hline Diabetes & $1(2.5 \%)$ & $1(2.6 \%)$ & $2(2.5 \%)$ & $0.004 ; 1.00$ \\
\hline \multicolumn{4}{|c|}{ Table 5. Differences in Comorbidities } \\
between Smoker \& Non-smoker COPD \\
\hline
\end{tabular}

\begin{tabular}{|c|c|c|c|}
\hline \multicolumn{4}{|c|}{ Gold COPD Classes A, B, C, D } \\
\hline FEV1<50\% & $\mathrm{C}$ & $\mathrm{D}$ & $\geq 1$ \\
\hline$>50 \%$ & $\mathrm{~A}$ & $\mathrm{~B}$ & 0 \\
\hline \multicolumn{4}{|c|}{ Table 6. GOLD COPD Classes } \\
\hline \multicolumn{4}{|c|}{} \\
\hline
\end{tabular}

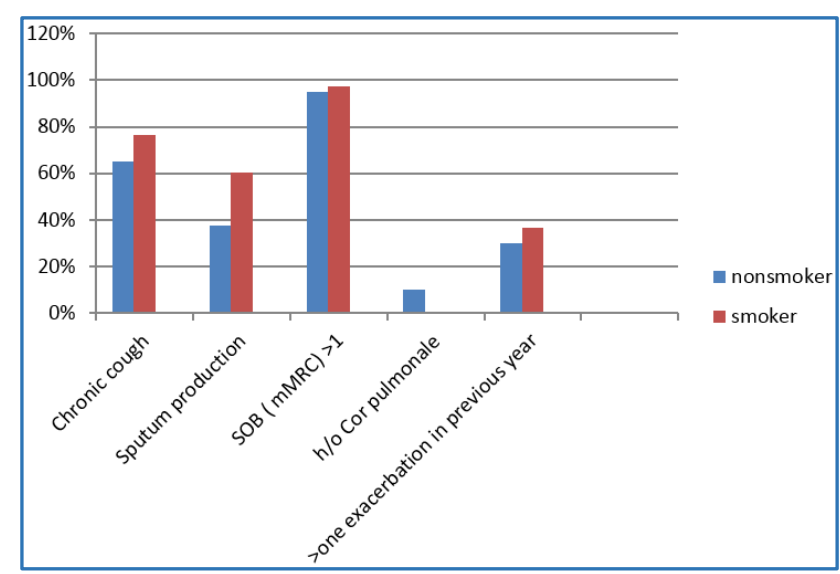

Figure 1. Clinical Difference between Smoker \& Non-smoker COPD

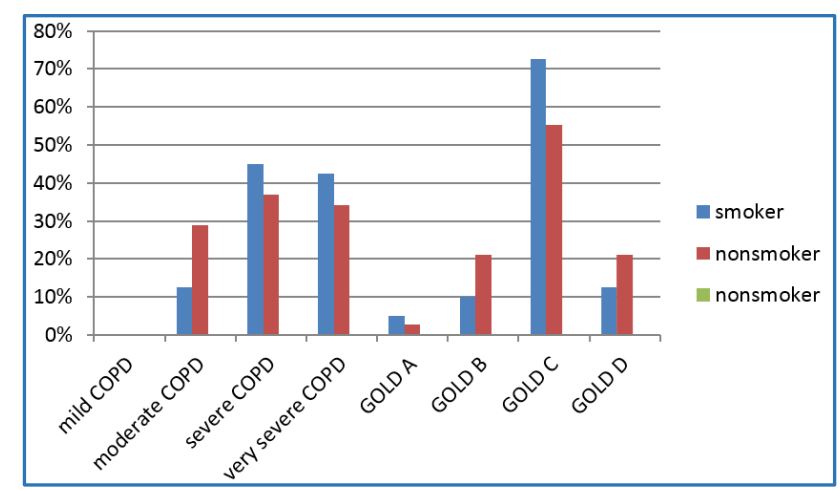

Figure 2. Severity \& Classes of COPD in Smoker \& Non-smoker COPD

\section{DISCUSSION}

A total of 78 consecutive patients in which 40 patients of smoker COPD \& 38 patients of non-smoker COPD were included in the study. Airflow obstruction (Percentage predicted FEV1) was found lower in smokers with COPD when compared to non-smoker COPD. This is because tobacco smoking leads to thickening and narrowing of the small conducting airways, along with destruction of the parenchyma and reduced alveolar-bronchiolar attachments. 10 Cough with expectoration, one of the classic features of COPD, is associated with exacerbations and both conditions are related to progressive loss of airflow. ${ }^{11}$ In this study, smokers with COPD reported significantly more chronic cough and sputum production than non-smokers. When we look for 
number of patients having more than one exacerbation in previous years, studies show that exacerbation was found more in smoker group than non-smoker which is similar to other studies. ${ }^{12}$ None of the patients in our study had malnutrition $(\mathrm{BMI}<20)$, but it was found lower for smoker COPD than non-smoker COPD which is in line with other studies. ${ }^{13}$ Our studies shows that severe \& very severe COPD was more prevalent in non-smoker when compared to smoker but moderate COPD was more frequent in smoker group. There are studies which show that smoking history does not appear relevant to determine severity of COPD which agree with our finding that higher number of cases with severe disease found in non-smoker group. ${ }^{14}$ Most of the patients of COPD belong to class $\mathrm{C}$ according to GOLD classification. Class A \& Class C COPD were more frequent in non-smokers, whereas Class B \& Class D were more frequent in smoker COPD. This reflects that patients who are smokers will be more symptomatic and more prone to exacerbation. If we look on comorbidities, hypertension was detected more in non-smoker COPD when compared to smoker COPD which is different from many studies, this could be due to a small sample size \& smoking duration.

\section{CONCLUSION}

COPD patients who are smokers have more symptoms of chronic bronchitis like cough with expectoration and have more frequent exacerbations when compared to nonsmokers. Hypertension and cor pulmonale was detected more in COPD patients who are non-smokers.

\section{Limitation of Studies}

The biggest limitation of this study could be the small sample size. We couldn't quantify smoking because most of the patients used bidi \& hukka and there was no method to quantify them similar to cigarette smoking. $P$ value is also not significant for most of the variables. COPD disease is associated with many comorbidities, but we assessed only diabetes \& hypertension.

\section{REFERENCES}

[1] Global Initiative for Chronic Obstructive Lung Disease. Global strategy for the diagnosis, management and prevention of COPD. 2013.

[2] Oswald NC, Medvei VC. Chronic bronchitis: the effect of cigarette-smoking. Lancet 1955;269(6895):843-4.

[3] Anderson DO, Ferris BG. Role of tobacco smoking in the causation of chronic respiratory disease. N Engl J Med 1962;267:787-94.
[4] Fletcher C, Peto R. The natural history of chronic airflow obstruction. BMJ 1977;1(6077):1645-8.

[5] Kohansal R, Martinez-Camblor P, Agusti A, et al. The natural history of chronic airflow obstruction revisited: an analysis of the Framingham offspring cohort. Am J Respir Crit Care Med 2009;180(1):3-10.

[6] Eisner MD, Anthonisen N, Coultas D, et al. An official American thoracic society public policy statement: novel risk factors and the global burden of chronic obstructive pulmonary disease. Am J Respir Crit Care Med 2010;182(5):693-718.

[7] Lamprecht B, McBurnie MA, Vollmer WM, et al. COPD in never smokers: results from the population-based burden of obstructive lung disease study. Chest 2011;139(4):752-63.

[8] Ramírez-Venegas A, Sansores RH, Pérez-Padilla R, et al. Survival of patients with chronic obstructive pulmonary disease due to biomass smoke and tobacco. Am J Respir Crit Care Med 2006;173(4):393-7.

[9] Shavelle RM, Paculdo DR, Kush SJ, et al. Life expectancy and years of life lost in chronic obstructive pulmonary disease: findings from the NHANES III follow-up study. Int J Chron Obstruct Pulmon Dis 2009;4:137-48.

[10] Gietema HA, Edwards LD, Coxson HO, et al. Impact of emphysema and airway wall thickness on quality of life in smoking-related COPD. Respir Med 2013;107(8):1201-9.

[11] Donaldson GC, Seemungal TA, Bhowmik A, et al. Relationship between exacerbation frequency and lung function decline in chronic obstructive pulmonary disease. Thorax 2002;57(10):847-52.

[12] Kim V, Garfield JL, Grabianowski CL, et al. The effect of chronic sputum production on respiratory symptoms in severe COPD. COPD 2011;8(2):114-20.

[13] Cano NJ, Pichard C, Roth H, et al. C-reactive protein and body mass index predict outcome in end-stage respiratory failure. Chest 2004;126(2):540-6.

[14] Gonçalves JR, Pereira MC, Magro DO, et al. Severe obstructive disease: similarities and differences between smoker and non-smoker patients with COPD and/or bronchiectasis. Rev Port Pneumol 2013;19(1):13-8. 